\title{
Agnieszka Wandel
}

Instytut Informacji Naukowej i Bibliotekoznawstwa Uniwersytet Wrocławski

e-mail: agnieszka.wandel@uwr.edu.pl

\section{Zarys dziejów encyklopedii dla dzieci i młodzieży w Polsce do 1989 roku $^{1}$}

\section{DOI: http://dx.doi.org/10.18778/0860-7435.24.03}

\begin{abstract}
Abstrakt: Celem tego artykułu jest zarysowanie historii edycji i kolejnych etapów w kształtowaniu się obecnej formy edytorskiej encyklopedii dla dzieci i młodzieży począwszy od 1. połowy XVIII wieku, a skończywszy na 1989 roku.
\end{abstract}

Słowa kluczowe: książka dla dzieci i młodzieży, książka popularnonaukowa, książka edukacyjna, wydawnictwo informacyjne

Współczesny rynek książki dla dzieci i młodzieży oferuje czytelnikom ogromny wybór różnego rodzaju wydawnictw encyklopedycznych. W świetle danych pochodzacych z reprezentatywnych źródeł informacji o książce (katalogu Biblioteki Narodowej i uzupełniajacco katalogów wybranych bibliotek publicznych, wydawnictw i księgarń) w latach 1990-2015 wydano w Polsce prawie 500 różnych encyklopedii dla dzieci i młodzieży (Wandel, 2017,

\footnotetext{
${ }^{1}$ Praca powstała w ramach realizacji projektu pn. Przemiany współczesnej ksiażki popularnonankowej dla dzieci i mtodzieży (na przyktadzie francuskiej oferty wydawniczej) finansowanego ze środków Narodowego Centrum Nauki przyznanych na podstawie decyzji numer DEC$-2013 / 11 / \mathrm{D} / \mathrm{HS} 2 / 04543$.
} 


\section{Agnieszka Wandel}

w druku). Oznacza to, że średnio każdego roku publikowano niemal 19 nowych dzieł tego typu. Jednocześnie są to wydawnictwa bardzo niejednorodne zarówno w treści, jak i w formie edytorskiej, a bliższy ogląd wielu z nich budzi wattpliwości, czy na pewno mamy w tym przypadku do czynienia z encyklopedia. Wyraźnym problemem stała się w ostatnich latach kwestia użycia, czy raczej nadużycia przez wydawców, określenia „encyklopedia”, stosowanego w tytułach dzieł lub serii wydawniczych i silnie eksponowanego typograficznie (najczęściej na pierwszej stronie okładki). Częstokroć w żaden sposób nie odzwierciedla ono rzeczywistości, a jest jedynie prostym zabiegiem marketingowym mającym uwiarygodnić „naukowość” danego dzieła. Rzutuje to oczywiście na postrzeganie tego typu publikacji przez czytelników i problemy z ich klasyfikacją w bibliotekach i księgarniach.

Z tej konstatacji zrodził się pomysł niniejszego badania, którego celem jest zarysowanie kolejnych etapów w rozwoju wydawnictw encyklopedycznych dla dzieci i młodzieży i odpowiedź na pytanie, czy przed 1989 r. istniał jednolity model tego typu publikacji i czy w związku z tym można mówić o klasycznym pierwowzorze gatunku. Dokonać tego chcemy poprzez analizę zmian $\mathrm{w}$ treści i formie proponowanych publikacji oraz przypomnienie najważniejszych tytułów encyklopedii, które na trwale zapisały się w dziejach wydawnictw informacyjnych dla najmłodszych.

Pod uwagę wzięto przede wszystkim encyklopedie opublikowane dla polskiego czytelnika (w tym adaptacje i tłumaczenia). Odwołania do wybranych edycji zagranicznych pozwoliły na osadzenie problematyki w nieco szerszym kontekście. Selekcjonując korpus do badań posłużono się przede wszystkim dostępna literatura przedmiotu oraz bibliografiami rejestrującymi książki dla dzieci i młodzieży (Boczar, 2010; Grefkowicz, 2005; Krassowska \& Grefkowicz, 1995; Neubert \& Lasiewicka \& Gutry, 1963; Neubert \& Lasiewicka, 1971). Celem tego opracowania nie jest jednak analiza ilościowa zebranego materiału, ale jakościowa ocena wybranych przykładów. Omówione dzieła zostały przebadane bądź z autopsji, bądź na podstawie ich reprodukcji cyfrowych dostępnych w Internecie (przede wszystkim w licznych bibliotekach cyfrowych).

$$
* * *
$$

Współcześnie «encyklopedią» nazywamy: „(1) dzieło obejmujące wiadomości ze wszystkich dziedzin wiedzy lub z jednej dyscypliny, ułożone alfabetycznie lub tematycznie” oraz „(2) zbiór wiadomości z zakresu danej dyscypliny nauki lub z różnych dziedzin" (Stownik jezyka polskiego PWN [online]), przy czym zarówno w bibliologii, jak i powszechnym użyciu, terminem tym 
posługujemy się zazwyczaj w pierwszym znaczeniu. Biorąc więc do ręki „encyklopedię" spodziewamy się dzieła zawierającego różnorodne informacje faktograficzne uporządkowane abecadłowo lub rzeczowo. Informacje te powinny być podane w postaci krótszych lub dłuższych artykułów (tzw. haseł), obejmować zaś moga całość (encyklopedie ogólne lub powszechne) lub określoną część wiedzy (encyklopedie specjalne) (por. Birkenmajer \& Kocowski \& Trzynadlowski, 1971, łam 669-672). Współczesny model encyklopedii kształtował się etapami od epoki oświecenia, a jedną z pierwszych i najbardziej znanych realizacji w tym zakresie była Wielka Encyklopedia Francuska (Encyclopédie on Dictionnaire raisonné des sciences, des arts et des métiers, tyt. w jęz. pol. Encyklopedia albo Stownik rozumowany nauk, sztuk i rzemiost) Denisa Diderota i Jeana d'Alemberta opublikowana w 35 tomach w latach 1751-1780.

Jeszcze wcześniej, bo w latach 1732-1750, również w Paryżu, ukazało się inne słynne dzieło wyrosłe na gruncie francuskiego oświecenia, określane niekiedy mianem pierwszej na świecie encyklopedii dla dzieci (Kątny, 2008, s. 43). Mowa tu o monumentalnym, ośmiotomowym dziele (w dziewięciu woluminach) duchownego Noëla-Antoine'a Pluche'a Le Spectacle de la nature. Obejmowało ono $\mathrm{w}$ formie rozmów młodzieńca $\mathrm{z}$ opiekunami szerokie spektrum wiedzy z zakresu nauk przyrodniczych i ścisłych, od zoologii po mechanikę. Nie była to jeszcze encyklopedia sensu stricto, ale układem treści, obecnościa materiałów pomocniczych oraz ambicją autora zmierzająca do całościowego ukazania omawianych zagadnień - bardzo się do tego typu publikacji zbliżała. Starannie wydane księgi zawierały dokładnie opisane ryciny ilustrujące omawiane zagadnienia, zwłaszcza nowo wprowadzane terminy zoologiczne, botaniczne lub techniczne; szczegółowy spis treści; żywą paginę boczną ułatwiająca orientację w tekście (zob. Rys. 1.) oraz indeks alfabetyczny. Dzieło było w owych czasach bestsellerem, a styl autora znalazł wielu naśladowców, co skutkowało wręcz wysypem podobnych publikacji o charakterze encyklopedyczno-podręcznikowym (rozmaitych zbiorów, rozmów, rysów). Od tego więc momentu datuje się intensywny rozwój różnego rodzaju wydawnictw informacyjnych i quasi-informacyjnych dla dzieci. 
Rys. 1. A.-N. Pluche, Le Spectacle de la nature

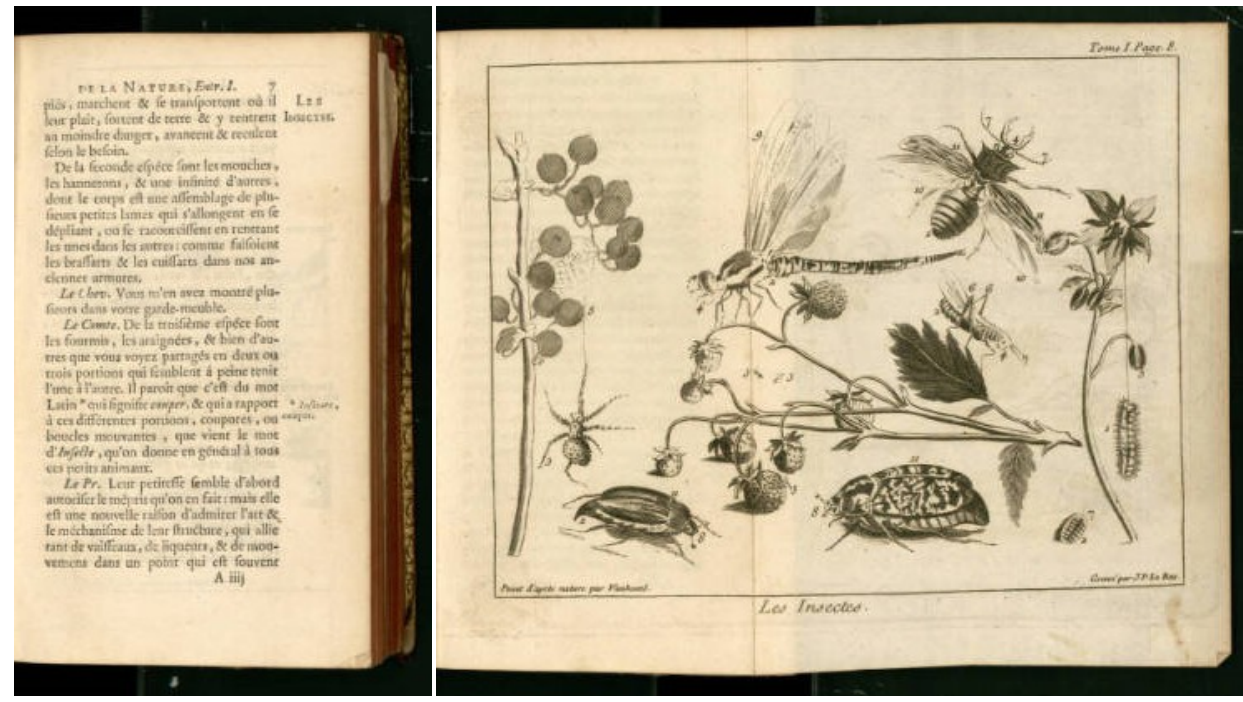

Źródło: biblioteka cyfrowa Uniwersytetu w Strasburgu, http://docnum.unistra.fr/cdm/

Za jedna z pierwszych polskich encyklopedii uniwersalnych dla młodocianych czytelników uznaje się kompilacyjne dzieło Michała Sołtyka, dziekana katedry krakowskiej, Encyklopedia wiadomości elementarnych czyli Pierwsze rysy

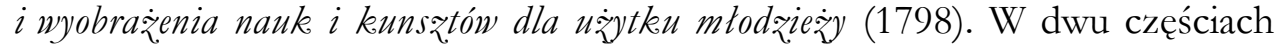
zebrał $\mathrm{w}$ nim autor podstawowe wiadomości i definicje $\mathrm{z}$ różnych dziedzin wiedzy (gramatyki, fizyki, anatomii itp.) oraz rzemiosł i sztuk (rolnictwa, mechaniki, a także muzyki, tańca itp.). Zastosował kryterium układu rzeczowego, przy czym kolejność poszczególnych haseł wynikała z subiektywnej hierarchii ważności (nieprzypadkowo przecież dzieło otwiera artykuł poświęcony religii). Artykuły hasłowe były bardzo rozbudowane (przedstawiały rys historyczny i stan współczesny omawianego zagadnienia), pełne anegdot i subiektywnych aluzji odautorskich (sprzecznych niekiedy, niestety, ze zdobyczami oświeceniowego racjonalizmu). Swoje opinie, silnie nacechowane światopoglądem chrześcijańskim, autor wyeksponował już w pierwszym rozdziale pisząc: Prayznaje sie wam, ze wspaniatość Pisma zadriwia mnie, świetość Ewangelii mówi do serca mojego (s. 4). Z edytorskiego punktu widzenia dzieło było wydane bardzo skromnie, w typowym podówczas formacie octavo (zbliżonym do współczesnych A5 lub B5), nie zawierało ilustracji i żadnych materiałów informacyjno-pomocniczych poza spisem treści (zob. Rys. 2). 
Rys. 2. M. Sołtyk, Encyklopedia wiadomości elementarnych....

(a) Spis treści poprzedzający zrąb główny, (b) Część rozdziału O Religii

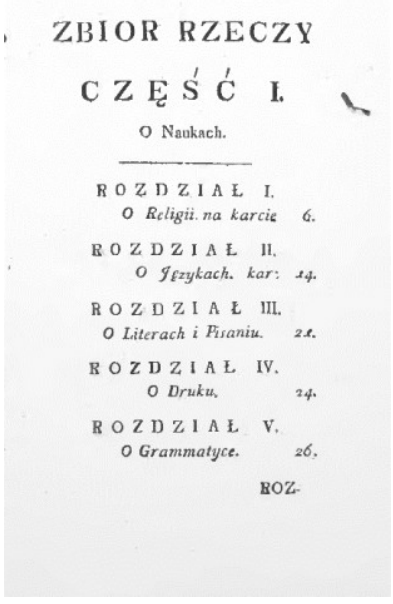

(a)

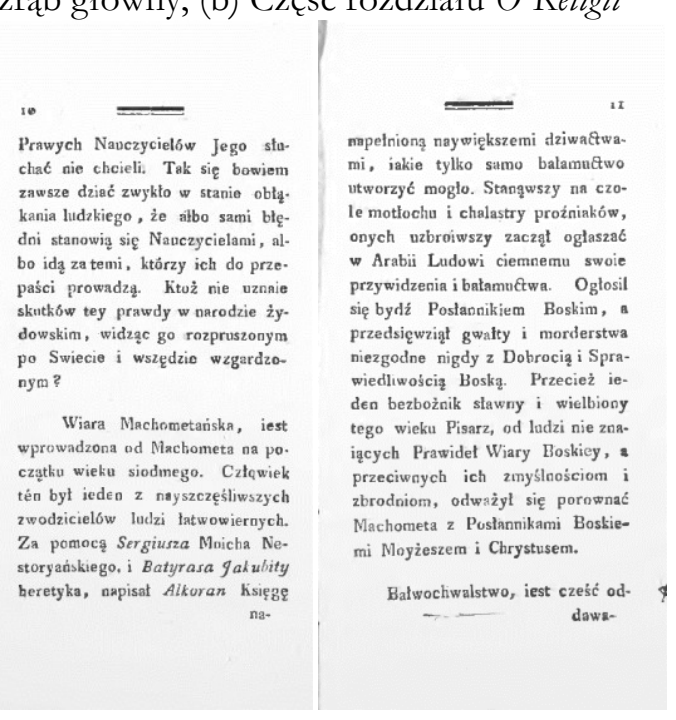

(b)

Źródło: Świętokrzyska Biblioteka Cyfrowa, http://sbc.wbp.kielce.pl/dlibra

Pod koniec XVIII wieku, pod wpływem sukcesu słynnych oświeceniowych encyklopedii dla dorosłych, ukształtował się jeszcze jeden, szczególny typ wydawnictwa encyklopedycznego. Mowa tu o bogato ilustrowanych dziełkach dla najmłodszych, swego rodzaju elementarzach zawierających podstawowe wiadomości z wybranych dziedzin. Publikacje te wyróżniała przede wszystkim luksusowa oprawa graficzna składająca się z licznych obrazków drukowanych na planszach. Poczatkowo takie dziełka sprowadzane były do Polski z zagranicy, tak jak Bilderbuch fur Kinder-Porte-feuille des enfants wydany w Weimarze w latach 1793-1830, zawierający w dwunastu tomach prawdziwe uniwersum wiedzy przedstawione w olbrzymiej liczbie miedziorytów ilustrujących postaci, przyrodę i przedmioty z opisami w postaci artykułów hasłowych w języku niemieckim i francuskim. Jedną z pierwszych polskich książeczek tego typu była Ksiega elementarna dla oświecenia drieci [...] (wyd. w 1817 r. przez W. B. Korna) zawierająca ryciny autorstwa m.in. Godfryda Chodowieckiego (brata słynnego Daniela) (zob. też: Dunin, 1991, s. 48-50)². Takie wydawnic-

\footnotetext{
${ }^{2}$ W późniejszym okresie, pod koniec XIX wieku podobne wydawnictwa - ograniczone tym razem niemal do samych obrazków, z bardzo niewielką ilością tekstu - tworzono na użytek propagowanej wtedy nowej metody nauczania elementarnego, tzw. nauki o rzeczach. Początkowo sprowadzane z zagranicy (głównie z Niemiec), potem opracowywane przez rodzimych autorów. Popularne były np. tablice M. Arct-Golaczewskiej Świat w obrazach (Warszawa 1890).
} 


\section{Agnieszka Wandel}

twa miały jednak bardzo ograniczone oddziaływanie, zważywszy na ich koszt, dostawały się jedynie do rąk dzieci pochodzących z najzamożniejszych rodzin.

Wiek XIX przyniósł wzmożony ruch w zakresie edycji różnorodnych wydawnictw informacyjnych dla dzieci i młodzieży. Zjawisku sprzyjał dominujący wciąż w literaturze dla najmłodszych nurt dydaktyczny, w drugiej połowie stulecia wzmacniany przez pozytywistyczne hasła kultu wiedzy. Nie bez znaczenia w tym kontekście była też społeczno-polityczna sytuacja Polski pod zaborami, która hamowała rozwój polskiego szkolnictwa i zarazem wpływała na konieczność i chęć domowej edukacji dzieci głównie w zakresie historii i literaturoznawstwa. W wyniku tego powstawały liczne dzieła o walorach poznawczych, kształcących, częstokroć o silnym zabarwieniu patriotycznym i wyraźnej funkcji użytkowej. Do tego ze względu na postęp w dziedzinie produkcji książek dla dzieci oraz skromniejszą formę tych edycji stopniowo poszerzały się kręgi ich odbiorców.

Opublikowano wtedy: Encyklopedie dla matych diqieci w przekładzie Jana Juliana Szczepańskiego (1842), Encyklopedie doreczna, çyli Zbiór ciekawych wiadomości dla panien Klementyny Hoffmanowej (wydane pośmiertnie, zredagowane z notatek autorki, 1851), Nowq encyklopedie dla diieci przez P.D. (1857), a także quasi-encyklopedyczne, gatunkowo synkretyczne Mate muгeum dla pilnych drieci (1830), Zbiór wsqystkich umiejętności dla mtodocianego wieku niezbednych J.M. Elkany (opracowanie dwujęzyczne polsko-francuskie, 1845-1856) itp. Dzieła te łączył syntetyczny charakter, próbowano w nich objąć całokształt wiedzy. Jednak dobór informacji - zarówno w sposobie opracowania siatki haseł, jak i konstrukcji poszczególnych artykułów hasłowych - był bardzo nierówny i zależał głównie od zasobu wiedzy oraz subiektywnego zamysłu autora (rzadkością były jeszcze wtedy encyklopedie wieloautorskie). W wielu publikacjach uprzywilejowane miejsce zajmowały wiadomości historycznoliterackie, w innych elementy nauk przyrodniczych i ścisłych (por. Piróg, 1983, s. 93). Przykładowo w Encyklopedii doręznej Hoffmanowej zdecydowanie dominowały treści humanistyczne, zwłaszcza odnoszące się do dziejów literatury i historii Polski, np. (Biblia, Biblioteki paryskie, Biblioteki we Wrocławiu, Chateaubriand, Jagietto, Kochanowski, Ksiażki w Polsce, Moda itp.), nauki ścisłe i stosowane reprezentowane były przez kilka zaledwie haseł (i to raczej w anegdotycznym zakresie, jak choćby Arytmetyka) $)^{3}$.

Podobne, Kolorowe tablice pogladowe (1889) - zestaw pouczających obrazków z wykazem pojęć w kilku językach - opracował też Adolf Dygasiński. Koncepcja edytorska tego typu dzieł zbliżona była w dużej mierze do współczesnych słowniczków obrazkowych.

${ }^{3}$ Wydawca zresztą zdawał sobie z tego doskonale sprawę, gdyż już w przedmowie do dzieła uściślił: Autorka tej Encyklopedyi, jak każda osoba poświęcajaca sie literaturze zwykta byla noto- 
Nieco innym rodzajem wydawnictwa encyklopedycznego były abecadlniki o charakterze encyklopedii specjalnej, obejmującej określoną dziedzinę wiedzy, np. tłumaczone z języka francuskiego Abecadło małego naturalisty - adaptacja słynnej Historii naturalnej Buffona (1820) czy Teofila Nowosielskiego Ilustrowany abecadlnik historyczny dla dieieci polskich (1862). Ich odbiorcami były z reguły młodsze dzieci.

Rys. 3. Charakter encyklopedii specjalnej nosił też Nowy Buffon dla młodzৃieży... (tu: tom IV, Warszawa 1806) z licznymi akwafortami przedstawiajacymi zwierzęta
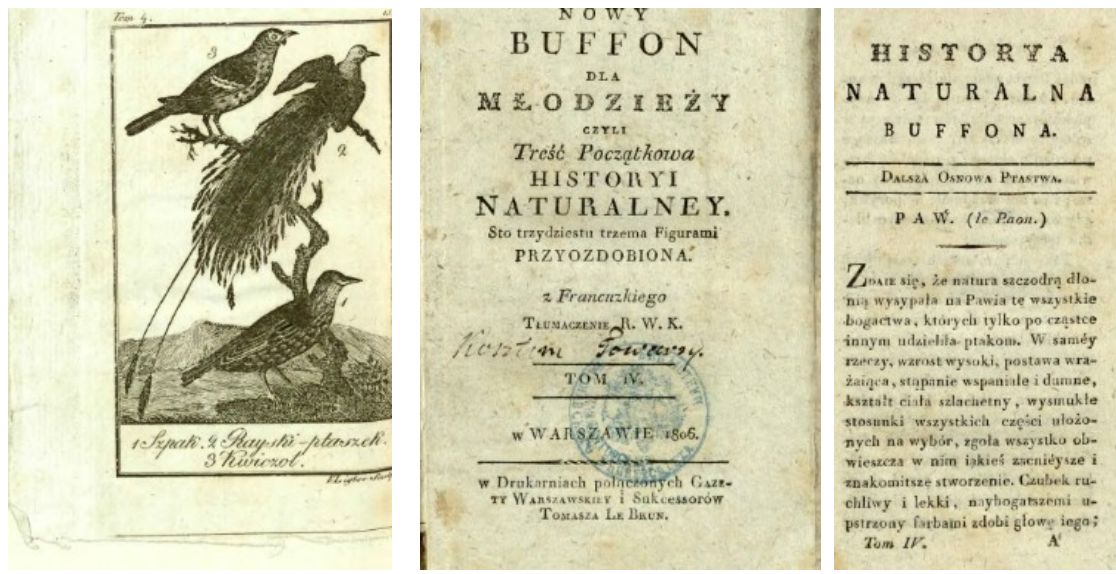

Źródło: Biblioteka cyfrowa Uniwersytetu Warszawskiego, http://ebuw.uw.edu.pl/dlibra

Zewnętrznie były to typowe dla edycji dziecięcych owych czasów niewielkie tomiki (o niemal kieszonkowym formacie, np. wysokość grzbietu dzieła Hoffmanowej to $17 \mathrm{~cm}$, jeszcze mniejsze było Muzeum dla pilnych drieci - $15 \mathrm{~cm}$ ) ze skromną szata graficzna. Ilustracje pojawiały się z rzadka (np. w Nowej encyklopedyi dla drieci przez P.D., która w trzech tomach obejmowała 952 strony było zaledwie 40 tablic z rycinami) lub nie było ich wcale, jak w Encyklopedii doręçnej, chociaż Zbiór wszystkich umiejetności zawierał ryciny kolorowe. Nieco bogatszą oprawę graficzna proponowały abecadlniki. Stosowano za to silne wyróżnienia typograficzne nagłówków haseł, co było bardzo ważne, ponieważ w większości przypadków artykuły były mocno rozbudowane, obejmując z reguły stronę lub dwie strony tekstu (por. Rys. 4.).

wać sobie wypadki, wiadomości, wyjatki z. cytowanych dĩet, które jej sie zdawaty godnemi u̇̇ytku w mnogich jej pracach literackich (s. 1). 
Rys. 4. K. Hoffmanowa, Encyklopedia doreczna....

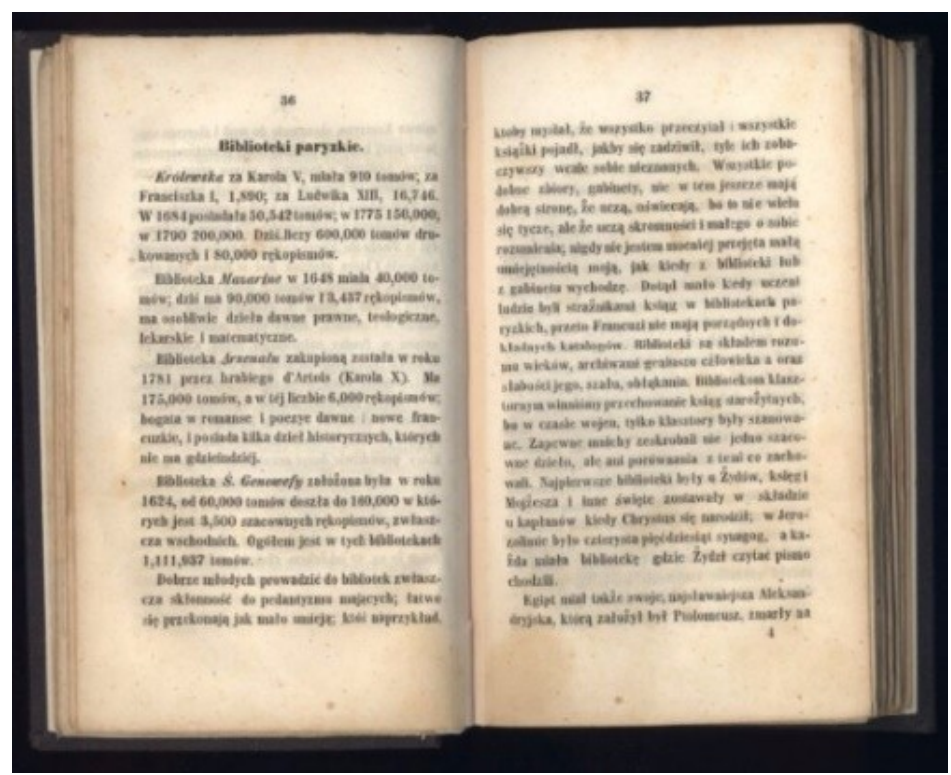

Źródło: Cyfrowa Biblioteka Narodowa Polona, https://polona.pl/item/411834/22/

Największym jednak mankamentem ówczesnych edycji encyklopedycznych był częsty brak konsekwencji w stosowaniu wygodnego dla użytkownika układu treści oraz niedociagnięcia w redagowaniu aparatu pomocniczego, np. brak spisu treści, (jak choćby w jednym z tomów Zbioru wsyystkich umiejętności) lub indeksu (choć np. w dziele Hoffmanowej ze względu na alfabetyczny układ całości zastosowano go zupełnie niepotrzebnie).

Ogromny skok jakościowy ${ }^{4} \mathrm{w}$ rozwoju encyklopedii dla dzieci dokonał się na przełomie XIX i XX wieku. Na powstawanie i odbiór społeczny tego typu wydawnictw ogromny wpływ miały wciąż jeszcze żywe echa pozytywistycznych ideałów upowszechniania wiedzy oraz wzmożony ruch w zakresie edycji podobnych publikacji dla dorosłych. W związku z postępująca podówczas mechanizacja procesów poligraficznych i dynamicznym rozwojem technik drukarskich otwarły się też w tej dziedzinie zupełnie nowe perspektywy edytorskie. Ukazały się wtedy dwie ważne encyklopedie uniwersalne z przeznaczeniem dla młodego czytelnika, które ze względu na późniejszy zastój na tym polu były wykorzystywane jeszcze długo, nawet w okresie dwudziestolecia międzywojennego. Mowa tu o Encyklopedii dla drieci Feliksa Boguckiego

\footnotetext{
${ }^{4} \mathrm{~W}$ przypadku encyklopedii dla dorosłych lub dla tzw. szerokiego kręgu odbiorców dokonał się też oczywiście niezwykły skok ilościowy.
} 
i Stanisława Krzemińskiego ${ }^{5}$ (1891; reprint 1990) oraz wydanej na Gwiazdkę 1899 roku Księdze ilustrowanej wiadomości pos̀ytecznych [...] (tyt. dzieł za: Lapeta-Golachowska, 1998, s. 134; nazwisko pierwszego autora podano zgodnie z opisem w katalogu NUKAT). Oba tytuły różniły się znacznie od wcześniej omawianych przykładów zarówno pod względem merytorycznym, jak i edytorskim. Po pierwsze, były wynikiem pracy zespołowej. Opracowania pierwszej z wymienionych encyklopedii podjęło się dwóch wybitnych publicystów; kolejna została zredagowana przez tak znanych popularyzatorów wiedzy, jak m.in. Maria Arctówna, Bogdan Dyakowski, Stanisław Kramsztyk i Wacław Nałkowski ${ }^{6}$. Wpływało to bezspornie na podniesienie wartości merytorycznej dzieła oraz uniknięcie dysproporcji pomiędzy podejmowanymi zagadnieniami. Po wtóre, zwiększył się znacznie format i objętość tych dzieł; sporych rozmiarów była zwłaszcza Encyklopedia Boguckiego i Krzemińskiego, której wysokość grzbietu wynosiła $25 \mathrm{~cm}$, z kolei Ksiega ilustrowana... przy nieco mniejszym formacie $(21 \mathrm{~cm})$ obejmowała ponad tysiąc stron. Były to już więc tomy zdecydowanie pokaźnych rozmiarów. Oba tytuły opracowane w układzie dwułamowym z żywa pagina, były bogato ilustrowane (czarno-białymi rycinami obłamanymi tekstem), zawierały krótkie, zobiektywizowane i ujednolicone pod względem długości i zakresu hasła, ułożone w porządku alfabetycznym (zob. Rys. 5.). Nowością w tych dziełach było też wprowadzenie systemu odsyłaczy (typu zob. w funkcji odsyłacza całkowitego lub uzupełniającego), które wskazywały użytkownikowi powiązania pomiędzy poszczególnymi hasłami. Tym samym zarówno sposobem opracowania, jak i zawartością zbliżyły się wyraźnie do modelu uniwersalnych encyklopedii dla dorosłych.

\footnotetext{
${ }^{5}$ Historyk, krytyk literacki Stanisław Krzemiński (1839-1912) miał ogromne doświadczenie w redagowaniu dzieł informacyjnych, był bowiem sekretarzem redakcji jednego z największych polskich przedsięwzięć encyklopedycznych - Wielkiej encyklopedii powszechnej ilustrowanej (Warszawa 1890-1914).

${ }^{6}$ Warto dodać, że druga z wymienionych encyklopedii według założeń redakcyjnych wyeksponowanych w przedmowie kierowana była do szerokiego grona odbiorców, w tym do młodzieży. Zapewne dlatego nie została ona odnotowana w bibliografii Elżbiety Boczar (2010).
} 
Rys. 5. Encyklopedya dla džieci. Uto żyli F.B. i S.K. [Bogucki \& Krzemiński] (1891)]
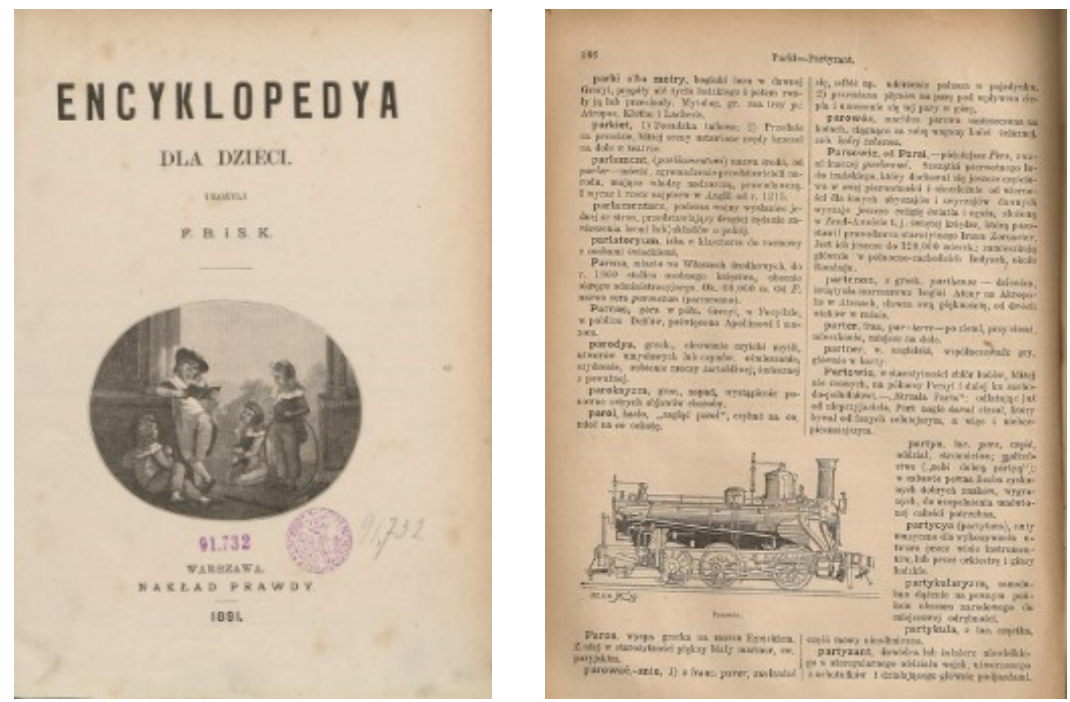

Źródło: Dolnośląska Biblioteka Cyfrowa, http://www.dbc.wroc.pl/dlibra

W okresie dwudziestolecia międzywojennego, pomimo olbrzymiej liczby edytowanych wtedy dzieł encyklopedycznych, nie ukazała się żadna tego typu publikacja z przeznaczeniem wyłącznie dla młodych czytelników. Korzystali oni zapewne ze słynnych ówczesnych encyklopedii, szczególnie tych ilustrowanych, które adresowane były do szerokiego kręgu odbiorców, np. Ilustrowanej encyklopedii Trzaski, Everta i Michalskiego (w 6 tomach, Warszawa 1925-1938 wraz z wydaniami skróconymi) lub Świata $i$ zycia: zarysu encyklopedycznego (w 5 tomach, Lwów 1933).

Sytuacja ta nie uległa znaczacej zmianie w okresie PRL. Ukazało się w tym czasie zaledwie kilka encyklopedii o charakterze uniwersalnym i specjalnym dla dzieci ${ }^{7}$, choć za granicą tego typu dzieł wychodziło sporo. Np. we Francji w edycji takich publikacji specjalizowało się wydawnictwo Larousse, które wypuściło na rynek ogromną liczbę „encyklopedycznych bestsellerów” doskonale zredagowanych pod względem merytorycznym i imponujących z punktu widzenia opracowania graficznego. W Polsce były symbolem najwyższej jakości i - długo niestety - niedoścignionym wzorem. Znaczne ożywienie w zakresie edycji wydawnictw encyklopedycznych dla dzieci na świecie

\footnotetext{
${ }^{7}$ Katalog Biblioteki Narodowej oprócz pozycji wymienionych w tekście podaje pod hasłem „encyklopedie dla dzieci” jeszcze dwa tytuły, a mianowicie Wyrazy trudne, ważne i ciekawe [...] (1. wyd. Warszawa 1977) oraz Śladami stów D. Goreckiej (Warszawa 1978). Nie są to jednak, encyklopedie sensu stricto, a leksykony, które są formą pośrednią między słownikiem a encyklopedia.
} 
datuje się od połowy lat siedemdziesiątych ubiegłego wieku. Wielotomowe uniwersalne publikacje informacyjne dla dzieci najczęściej w układzie alfabetycznym zaczęły wtedy publikować najbardziej renomowane wydawnictwa, m.in. Oxford University Press, Encylopaedia Britannica Educational Corp., Collins, Usborne, Larousse, Hachette, Leipzig Verlag Enzyklopädie itp. Olbrzymią encyklopedię dla dzieci obejmującą w 12 tomach ponad sześć tysięcy stron wydano nawet w ZSRR (Dietskaja enciktopedia). W kolejnych dekadach triumf przeżywały edycje bogato ilustrowanych kolekcji encyklopedycznych, tj. serii książek, z których każda poświęcona była odrębnemu zagadnieniu, ale jako całość mogły stanowić swoiste uniwersum wiedzy. Wchodzące w skład takich serii tomiki najczęściej prezentowały informacje w układzie rzeczowym, który ułatwia percepcję treści i zachęca młodego czytelnika do przestudiowania całości dzieła. Przykładowo współpraca francuskiego wydawnictwa Gallimard z brytyjskim Dorling Kindersley doprowadziła do powstania jednej z najbardziej uznanych serii tego typu „Eyewitness wallcharts” (franc. „Les Yeux de la Découverte”) obejmującej kilkadziesiąt tytułów książek. W polskich tłumaczeniach niektóre z tych dzieł ukazały się dopiero po 1989 roku.

W Polsce w latach 1945-1989 rynek encyklopedii dla dzieci i młodzieży był jednym z najbardziej zaniedbanych segmentów rynku książki. Głównym powodem takiego stanu rzeczy był katastrofalny stan ówczesnej poligrafii. Do nielicznych opublikowanych wtedy wydawnictw encyklopedycznych należą zwłaszcza dwa, bardzo znane tytuly: Polska, moja ojczyzna. Encyklopedia dla dzieci (1. wyd. 1976, kolejne 1978 i 1979) oraz O ksiażce. Mała encyklopedia dla nastolatkón (1987). Pierwsza z wymienionych publikacji była w tym okresie właściwie jedyną encyklopedią uniwersalną dla dzieci starszych i młodzieży w pełni zasługująca na to miano. Ambicją jej autorów było objąć szerokie spektrum zagadnień dotyczących wszystkich aspektów przeszłości i teraźniejszości naszego kraju: geografii, gospodarki, kultury itp. Na pięciuset stronach w układzie abecadłowym, w dwóch łamach ujęto 240 rozbudowanych, przeglądowych haseł. Na tle ówczesnej produkcji ta sporych rozmiarów księga (o wysokości grzbietu $31 \mathrm{~cm}$ ) imponowała rozmachem opracowania edytorskiego (twarda, kolorowa lakierowana okładka, szyty blok książki, ogrom barwnych i czarno-białych ilustracji - fotografii i rysunków), stąd cieszyła się ogromna popularnością (miała aż trzy wydania).

Niestety, do historii przeszła $z$ innego powodu, była bowiem typowym przykładem socjalistycznego wydawnictwa propagandowego. Zawierała mnóstwo nieprawdziwych informacji i przekazywała fikcyjny, zgodny z ideologia sukcesu lat siedemdziesiątych wizerunek Polski. Zafałszowaniu uległa zwłaszcza historia najnowsza, tj. dotycząca dwudziestolecia międzywojennego, 


\section{Agnieszka Wandel}

w tym osiagnięć II Rzeczpospolitej, roli Piłsudskiego w budowie odradzającej się ojczyzny, wojny polsko-bolszewickiej itp., a także czasów II wojny światowej i całego okresu Polski Ludowej. Faktycznym celem tej publikacji było w zasadzie pod pozorem rzetelnego wydawnictwa informacyjnego rozpowszechnianie określonej ideologii i promowanie jedynej słusznej wówczas postawy obywatelskiej. Służyć temu miała odpowiednio skonstruowana siatka haseł oraz budowa i stylistyka artykułów hasłowych, w których to elementach pewne fakty eksponowano, a inne przemilczano (tematami tabu były Szare Szeregi, Powstanie Warszawskie, pochodzenie Janusza Korczaka i wiele innych). Do tego publicystyczny język dzieła podporządkowany był przekazywaniu „właściwej” wizji i interpretacji faktów, nie zaś zobiektywizowanej informacji (słowa-klucze to „postępowy” kontra „wsteczny”, „burżuazyjny” kontra „rewolucyjny”, „wyzysk” kontra „sprawiedliwość społeczna” itp.), a okazała forma edytorska dzieła miała dodatkowo wzmacniać przekaz. Dość powiedzieć, że Halina Skrobiszewska w doskonałej, merytorycznej recenzji tego dzieła, którą notabene ze względów politycznych opublikowano dopiero w początkach lat dziewięćdziesiątych, już po śmierci jej autorki, uznała je za jedna z najszkodliwszych publikacji dla dzieci wydanych w latach siedemdziesiątych (1996).

Zupełnie inne skojarzenia budzi kolejna wymieniona encyklopedia $O$ ksiażce, tym razem specjalna, z zakresu księgoznawstwa. Zawierała około 500 haseł w układzie alfabetycznym, napisanych jasnym, zrozumiałym językiem, a obejmujących zagadnienia edytorstwa, drukarstwa, księgarstwa, bibliotekarstwa itp., np. Redakcja, Cqcionka, Encyklopedia, Aukcja, Bibliobus itp. Przedmowa i opracowanie redakcyjne tomu zapoznawały młodych czytelników z budową i sposobem opracowania wydawnictw informacyjnych. Odpowiadały więc np. na pytania, czym jest hasło główne, a czym hasła powiązane, co to jest odsyłacz i jakie sa ich rodzaje. Doskonale opracowana pod względem merytorycznym (przy współpracy wybitnych pracowników nauki, m.in. Radosława Cybulskiego, Heleny Hleb-Koszańskiej, Krzysztofa Migonia) i edytorskim (w niezapomnianej oprawie graficznej Bohdana Butenki) była prawdziwą perłą wśród ówczesnych dziełek popularnonaukowych.

Przytoczone powyżej przykłady sa na ogół dobrze znane i wymagały jedynie przypomnienia. Tymczasem warto wspomnieć o jeszcze jednej publikacji, trochę dziś zapomnianej, a jednak ważnej, bo w dziejach edycji wydawnictw informacyjnych dla najmłodszych w okresie PRL stanowiącej swoisty ewenement. Mowa tu o encyklopedii Świat driecka przetłumaczonej z języka francuskiego (tyt. oryg. Mon premier Larousse en couleur), a wypuszczonej na rynek w 1960 r. przez wydawnictwo „Wiedza Powszechna”. Adresowana do najmłodszych czytelników (jak zaznaczono w przedmowie - do dzieci od 
pięciu do ośmiu lat) nosiła podtytuł Moja pierws za encyklopedia, choć z definicyjnego punktu widzenia była właściwie słownikiem encyklopedycznym. Z typowymi dla encyklopedii hasłami faktograficznymi sąsiadowała bowiem spora liczba haseł objaśniających znaczenia słów oraz przykłady ich użycia. Ta sporych rozmiarów książka, o nietypowym formacie $28 \times 33 \mathrm{~cm}$, była bardzo starannie wydana. Wyróżniała ją twarda, lakierowana oprawa i mnóstwo kolorowych ilustracji. Badacza książki okresu PRL zadziwia w niej jednak nie tylko piękno szaty graficznej, ale przede wszystkim niemal całkowity brak elementów indoktrynacji politycznej. Jak podkreślono w przedmowie - wydawnictwo było w zasadzie wiernym przekładem oryginału (usunięto zaledwie kilka haseł typowych dla francuskiej rzeczywistości i niezrozumiałych dla polskiego dziecka, w zamian dodając parę haseł nowych, w tym oczywiście Polska i Polak/Polka; zmianie uległo też kilka objaśnień, stąd np. w haśle „święto" znalazła się jednak informacja o peerelowskich obchodach 22 lipca). Encyklopedia ta może być przykładem wzorcowej adaptacji, zadbano w tym celu o najmniejsze szczegóły zarówno w tekstach haseł, jak i w rysunkach, stąd np. podaje, że na śniadanie jemy chleb, a nie bułkę paryską z marmolada, na obiad zaś kapuśniak, a nie ratatouille; na podobnej zasadzie - hasło „mapa” zostało zilustrowane mapa Polski, podobnie jak hasło sztandar - polską flagą.

Podobne dzieła publikowane na licencjach zachodnich wydawnictw były w okresie PRL wielką rzadkością (choć w latach siedemdziesiątych „Naszej Księgarni” udało się wydać inny ówczesny popularnonaukowy bestseller Larousse'a, a mianowicie Ziemie, rośliny, zwierzeta).

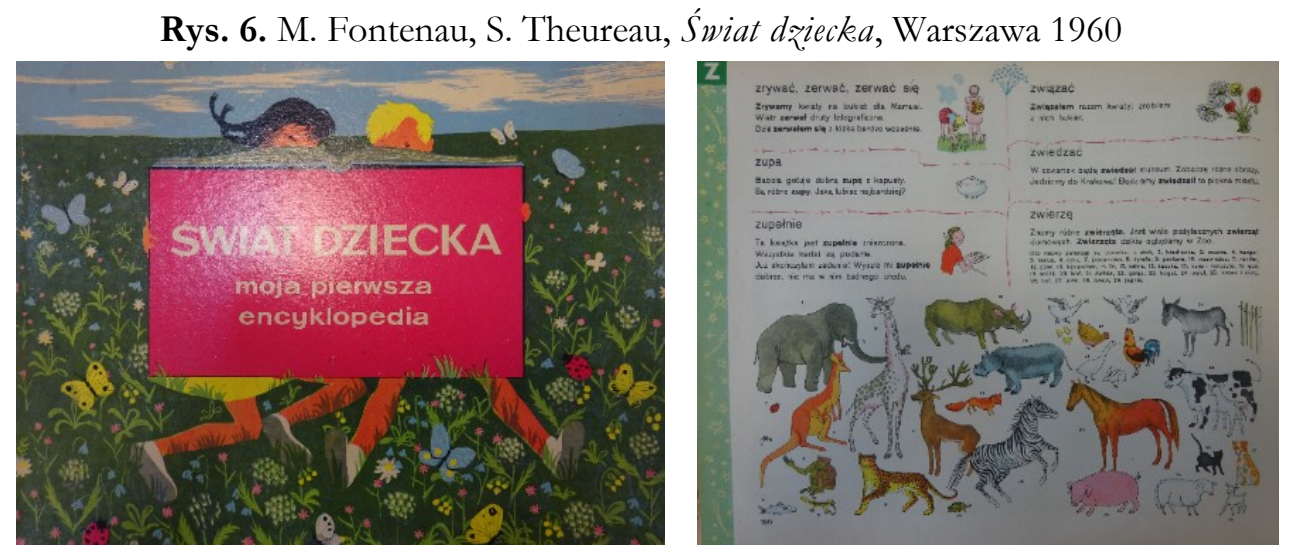

Źródło: fotografia autorki.

W podobnym duchu, choć zupełnie innym układzie (w podziale na działy tematyczne), powstała w połowie lat osiemdziesiątych znana i bardzo lubiana przez dzieci encyklopedia Poznaje swiat: ksiażka dla dzieci 6-8 letnich według 


\section{Agnieszka Wandel}

scenariusza Ireny Słońskiej (ogółem dwa wydania) w pięknym opracowaniu graficznym, z ilustracjami m.in. Mateusza Gawrysia, Janusza Grabiańskiego oraz Janusza Stannego. Bezpośrednią inspiracją dla tego tomiku była słowacka (wtedy czechosłowacka) publikacja Svet około nas (Bratysława 1964).

$$
* * *
$$

W dziejach edycji wydawnictw encyklopedycznych dla dzieci i młodzieży wyróżnić można kilka etapów. W pierwszym okresie powstawania tego typu publikacji, a więc od połowy XVIII do połowy XIX wieku, dominowały na rynku encyklopedie jednoautorskie, $\mathrm{z}$ reguły o uniwersalnym charakterze, ale za to silnie zindywidualizowanym sposobie prezentacji informacji. Celem tych wydawnictw było nie tylko przedstawienie konkretnych faktów, ale także promowanie określonego światopoglądu. Stąd liczne luki w konstrukcji siatki haseł (doborze podejmowanych zagadnień), przewaga mocno rozbudowanych, przeglądowych artykułów oraz brak obiektywizmu w ich opracowaniu. $\mathrm{Z}$ edytorskiego punktu widzenia były to niewielkie, skromnie ilustrowane tomiki, ze słabo rozbudowanym aparatem pomocniczym (obejmującym zazwyczaj jedynie spis treści dzieła).

Do dużych zmian w redagowaniu tego typu publikacji doszło na przełomie XIX i XX wieku. W warstwie merytorycznej, dzięki zespołowej redakcji nowo powstających wydawnictw, zaczęto dążyć do zapewnienia równowagi pomiędzy prezentowanymi zagadnieniami oraz ujednolicenia i zobiektywizowania treści haseł. Ponadto zwiększające się możliwości techniczne pozwalały na edycję dzieł w układach dwułamowych z bogatszym wyposażeniem graficznym o zwiększonym formacie i objętości. Objętość artykułów hasłowych uległa znaczącemu skróceniu, nowością z punktu widzenia opracowania redakcyjnego było też wprowadzenie systemu odsyłaczy. Wszystko to sprawiło, że ówczesne encyklopedie dla dzieci w dużej mierze upodobniły się to tego rodzaju wydawnictw adresowanych do czytelnika dorosłego.

W okresie PRL udoskonalono opracowanie redakcyjne encyklopedii, m.in. poprzez wprowadzenie przedmowy zapoznającej czytelnika z zasadami korzystania z tego typu dzieł. Po raz kolejny zwiększył się format tych wydawnictw, uatrakcyjnieniu uległa także ich szata graficzna (lakierowana okładka, barwne ilustracje, fotografie itp.). Nie bez powodu encyklopedie $z$ tego okresu kojarzą się zazwyczaj z okazałą formą, która była zewnętrznym atrybutem poważnego opracowania. Dzieła komponowano z reguły w układzie alfabetycznym, brakowało natomiast na rynku wydawnictw encyklopedycznych dziedzinowych w układzie rzeczowym (bardzo już wtedy popularnych w innych krajach) - najlepiej dostosowanych do możliwości percepcyjnych młodych czytelników. 
Ostatecznie można stwierdzić, że przed 1989 r. doszło do wypracowana pewnego modelu encyklopedii dla dzieci i młodzieży, którego najważniejszymi cechami były: pokaźny format, najczęściej dwułamowy, alfabetyczny układ oraz dążenie do uniwersalnego charakteru. Zewnętrznie dzieła te z reguły przypominały publikacje dla czytelników dorosłych, z merytorycznego punktu widzenia natomiast służyły częstokroć nie tylko przekazywaniu zobiektywizowanej informacji, ale również kształtowaniu określonego światopoglądu.

Przedstawiony powyżej skromny dorobek nieco ponad dwustu lat polskich wydawnictw encyklopedycznych dla dzieci został pomnożony do niezwykłych wręcz rozmiarów po 1989 roku. W tym czasie nastąpiły ogromne zmiany w edycji tego typu dzieł (związane przynajmniej początkowo głównie $z$ napływem ogromnej liczby encyklopedii wydawanych na zagranicznych licencjach), co doprowadziło do znacznego odejścia od wcześniej wypracowanych form i pojawienia się wielu nowatorskich rozwiązań, a nawet zupełnie nowych typów wydawnictw paraencyklopedycznych (Wandel, 2017).

\section{Bibliografia podmiotowa}

Abecadto matego naturalisty czyli Poczqtkowe wiadomości bistoryi naturalney ozdobione rycinami (1820). [Na podstawie Historii Naturalnej Buffona].Warszawa: N. Glücksberg.

Bilderbuch fur Kinder-Porte-feuille des enfants (1793-1830). T. 1-12, Weimar: F. J. Bertuch.

Bogucki, Feliks \& Krzemiński, Stanisław (1891). Encyklopedya dla drieci. Warszawa: „Prawda”. Reprint Wydawnictwa Artystyczne i Filmowe 1990.

Elkana, Michalina J. (1845-1856). Zbiór wsyystkich umiejętności dla mtodocianego wieku niezbednych, t. 1, Bóg, ziemia, çłowiek, historya naturalna, geografia, astronomia, fizyka, gramatyka, arytmetyka, siedm cudów swiata, t. 2, Historya święta, rzut oka na Historya Nowego Testamentu, t. 3, Dzieje Egipcyan, Greków i Rzymian, mitologia, historya powszechna, historya polska, historya Rossyi, technologia. Warszawa: S. H. Merzbach.

Fontenau, Marthe \& Theureau, S. (1960). Świat driecka. Warszawa: „Wiedza Powszechna”.

Hoffmanowa, Klementyna (1851). Encyklopedia doreczna, cayli Zbiór ciekawych wiadomości dla panien Klementyny. T. 1-2. Warszawa: S. Orgelbrand.

Ksiega elementarna dla oświecenia dzieci, czyli pierwsze wiadomości każdego rodzaju w obrazach wystawionych podtug dzieła niemieckiego Pana Profesora Stoy w jezyku francuskim wydane przez Perrault (1817). Wrocław: Wilhelm Bogumił Korn.

Ksiega ilustrowana wiadomości pożytecznych: podręznik encyklopedyczny z dziedziny: aeronautyki, anatomii, architektury, astronomii, botaniki, chemii, elektrotechniki, fiayki, fiayologii, geologii, geografii fizycznej, bygieny, kosmografii, matematyki, medycyny, mineralogii, meteorologii, ogrodnictwa, przemystu, rolnictwa, sz̧tuki, technologii, wojskowości, zoologii, żeglarstwa objaśniony 2500 rysunkami. Księze ilustrowanej wiadomości pożytecznych (1899). Warszawa: Michał Arct.

Lalourcey (1806). Nowy Buffon dla młodzieży czyli treść poczatkowa historyi naturalnej. Tłum. Wincenty Roch Karczewski. Warszawa: Druk. Gazety Warszawskiej i Suk. T. Le Brun.

Markuševič, Aleksej I. (red.) (1971-1977). Dietskaja encikłopedia. T. 1-12. Moskwa: Pedagogika. 


\section{Agnieszka Wandel}

Mate muzeum dla pilnych dzieci (1830). T. 1-2. Warszawa: A. Brzezina.

Nowosielski, Teofil (1862). Ilustrowany abecadlnik historyczny dla drieci polskich. Warszawa: nakładem A. Nowoleckiego.

O ksiażce. Mała encyklopedia dla nastolatkón (1987). Wrocław: „Ossolineum”.

P.D. (1857). Nowa encyklopedya dla dzieci. T. 1-3. Warszawa: [s.n.].

Pluche, Noël Antoine (1732-1750). Spectacle de la nature, on Entretiens sur les particularités de l'bistoire naturelle qui ont paru les plus propres à rendre les jeunes gens curieux et à leur former l'esprit, 9 vols. Paris: Chez la veuve Estienne \& fils.

Polska - moja ojczyzna. Encyklopedia dla dzieci (1976). Warszawa: „Wiedza Powszechna”.

Sołtyk, Michał (1798). Encyklopedia wiadomości elementarnych czyli Pierwsze rysy i wyobrażenia

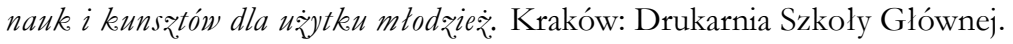

Szczepański, Jan J. (przekł.) (1842). Encyklopedia dla małych dzieci. Lwów: Druk. Piotra Pillera.

\section{Bibliografia przedmiotowa}

Birkenmajer, Aleksander \& Kocowski, Bronisław \& Trzynadlowski, Jan (red. nacz.) (1971). Encyklopedia wiedzy o ksiqżce. Wrocław: Zakład Narodowy im. Ossolińskich

Boczar, Elżbieta (2010). Bibliografia literatury dla dzieci i młodzie $\dot{z} y$ - wiek XIX: literatura polska i przekłady. Warszawa: Wydawnictwa Uniwersytetu Warszawskiego.

Dunin, Janusz (1991). Ksiażeczki dla grzecznych i niegrzecznych dzieci. Z dziejów polskich publikacji dla najmłodszych. Wrocław: Zakład Narodowy im. Ossolińskich - Wydawnictwo.

Grefkowicz, Alina i in. (oprac.) (2005). Bibliografia literatury dla dzieci i młodzie ży 1901-1917: literatura polska i przekłady. Warszawa: Biblioteka Publiczna m.st. Warszawy - Biblioteka Główna Województwa Mazowieckiego.

Kątny, Marek (2008). Droga do wiedzy: o literaturze popularnonankowej dla mtodego odbiorcy, Kielce: Gens.

Krassowska, Bogumiła \& Grefkowicz, Alina (oprac.) (1995). Bibliografia literatury dla dzieci i młodzieży 1918-1939: literatura polska i przektady. Warszawa: Biblioteka Publiczna m.st. Warszawy.

Lapeta-Golachowska, Bożena (1998). Książka popularnonaukowa dla dzieci i młodzieży do roku 1918. W: K. Heska-Kwaśniewicz, I. Socha (red.), Ksiażka dla driecka: wczoraj, dziis, jutro (s. 126-148). Katowice: Wydawnictwo Uniwersytetu Śląskiego.

Neubert, Felicja \& Lasiewicka, Alina (1971). Bibliografia literatury dla diqieci 1945-1960: przekłady, adaptacje. Warszawa: Stowarzyszenie Bibliotekarzy Polskich.

Neubert, Felicja \& Lasiewicka, Alina \& Gutry, Maria (1963). Bibliografia literatury dla dzieci 1945-1960: literatura polska. Warszawa: Stowarzyszenie Bibliotekarzy Polskich.

Piróg, Iwona (1983). Książka popularnonaukowa dla dzieci i młodzieży na ziemiach polskich w latach 1830-1863. Studia o Ksiażce, 13, 71-110.

Przyłubski, Feliks (1964). O encyklopediach dla dzieci i młodzieży. Z Doświadczeń Bibliotek Szkolnych i Pedagogicznych, $V$, 60-65.

Skrobiszewska, Halina (1993). Encyklopedia dla dzieci nie jest wydawnictwem informacyjnym. Guliwer, 4, 46-53. 
Słownik języka polskiego PWN [online] Warszawa, Wydawnictwo Naukowe PWN. Pobrane 12 czerwca 2016, z: http://sjp.pwn.pl

Wandel, Agnieszka (2017, w druku). Współczesne encyklopedie dla dzieci i młodzieży - analiza księgoznawcza (1990-2015). W: M. Antczak (red.), Inspiracje caytelniçe w życiu mtodego pokolenia.

Zając, Michał (2013). Książki edukacyjne dla dzieci i młodzieży: wczoraj, dziś i jutro. W: G. Leszczyński, M. Zając, Ksià̇ka i młody czytelnik: zbliżenia, oddalenia, dialogi: studia $i$ szkice (s. 259-267). Warszawa: Wydawnictwo SBP.

\section{An outline history of the encyclopaedias for children and youth in Poland until 1989}

ABSTRACT: The aim of the paper is to depict the history of editions and the subsequent stages in the formation of the editorial form of encyclopaedias for children and youth from the first half of the eighteenth century through to 1989 years.

KEYWORDS: book for children's and youth, popular science book, non-fiction book, informational book 